\title{
Chapter 21 \\ Recycling Mine Tailings for a Sustainable Future Built Environment
}

\author{
Surya Maruthupandian, Napoleana Anna Chaliasou, \\ and Antonios Kanellopoulos
}

\begin{abstract}
The future sustainable built environment focuses mainly on environmental conservation and technological innovation and development. However, with infrastructure development, the consumption of raw materials such as cement, gypsum, sand, and stones increases. Therefore, use of industrial waste as raw material in construction shall be proposed as a sustainable and environment friendly alternative. Also, the higher demand for mineral commodities have led to increased mining and hence increased mining waste. The mine tailings being the wastes from rocks and minerals processing, are generally rich in $\mathrm{Si}, \mathrm{Ca}, \mathrm{Al}, \mathrm{Mg}$, and $\mathrm{Fe}$, and also have considerable amounts of heavy metals and metalloids such as $\mathrm{Pb}, \mathrm{As}, \mathrm{Co}, \mathrm{Cu}, \mathrm{Zn}$, $\mathrm{V}$, and $\mathrm{Cr}$. When tailings contain sulphide minerals, it may also lead to acid mine drainage. This makes the effective and efficient recycling and reuse of mine waste a major environmental concern. However, the physical, mineralogical and chemical composition of the mine tailings renders it a suitable material for use in civil engineering applications. This paper discusses the use of mine tailings of different origins for different civil engineering applications such as bricks, ceramics, fine aggregates, coarse aggregate and cementitious binders. This approach has a potential to reduce the demand on existing natural resources to face the demands of the exponentially developing infrastructure.
\end{abstract}

Keywords Sustainable construction $\cdot$ Mine wastes $\cdot$ Mine tailings $\cdot$ Reuse and recycle

\subsection{Introduction}

Environmental conservation and technological innovation and development are the major focus of future sustainable built environment [1]. Thus sustainable utilization of industrial wastes in civil engineering applications shall be a viable approach to

S. Maruthupandian $(\bowtie) \cdot$ N. A. Chaliasou $\cdot$ A. Kanellopoulos School of Engineering \& Computer Science, Materials \& Structures Research Group, University of Hertfordshire, Hatfield, United Kingdom e-mail: s.maruthupandian@herts.ac.uk 
meet the demands of raw materials such as cement, sand, aggregates, backfill soil and gypsum associated with rapid infrastructure development and spreading built environment.

Also, with the rapid development the demand for mineral commodities has increased leading to increase in mining operations. This leads to production of mining waste including waste rocks, over burden soil and mine tailings [2]. The fine-grained mineral waste left after removal of valuable material from ore is called mine tailing and is the major waste of mining processes [3]. This paper focuses on providing ways of utilization of mine tailings in different civil engineering applications.

\subsection{Mine Tailings}

The mining operations lead to a production of 20-25 billion tonnes of solid wastes every year, of which mine tailings constitute about 5-7 billion tonnes. [4]. These tailings are generally disposed, either by direct disposal of tailings in rivers, seas or disposal in form of slurry (25-30\% solid) into a cell, confinement or dam [5]. Mine tailing management is a crucial issue as the physico-chemical characteristics of the wastes have severe impact on the soil and water, some of the more severe ones being acid mine drainage and leaching of heavy metals.

\subsubsection{Properties of Mine Tailings}

Mine tailings in general are crystalline, relatively loose and have a porous microstructure [6]. The specific gravity of the mine tailings was between 2.7-4.29 [7], [8] and the particle size of mine tailings varied amongst cement sized, silt sized and sand sized particles [9]. The water absorption was reported to be up to $7.15 \%$ [10] and $\mathrm{pH}$ values of the tailings were in near neutral or slightly alkaline region generally ranging between 6.69-10 [11-13]. The composition varied highly due to the variation in source mineral, process of extraction, mineral extracted and quality of the ore [14]. Most of the mine tailings were predominantly silicates and the distribution of major chemical oxides of different mine tailings is given in Fig. 21.1. The presence of heavy metals such as $\mathrm{Pb}, \mathrm{Zn}, \mathrm{Cd}, \mathrm{Cu}, \mathrm{Ar}, \mathrm{Cr}, \mathrm{V}, \mathrm{Zr}$ poses a danger of leaching into the environment [15]. Mine tailings with sulphide minerals such as pyrite, arsenopyrite and pyrhottite [16] reacts with oxygen and water and cause acid mine drainage [9].

\subsection{Research Trends for Application in Built Environment}

Mine tailings are suitable for various civil engineering applications due to its physical and chemical properties. However, heavy metals leaching and acid mine drainage are 


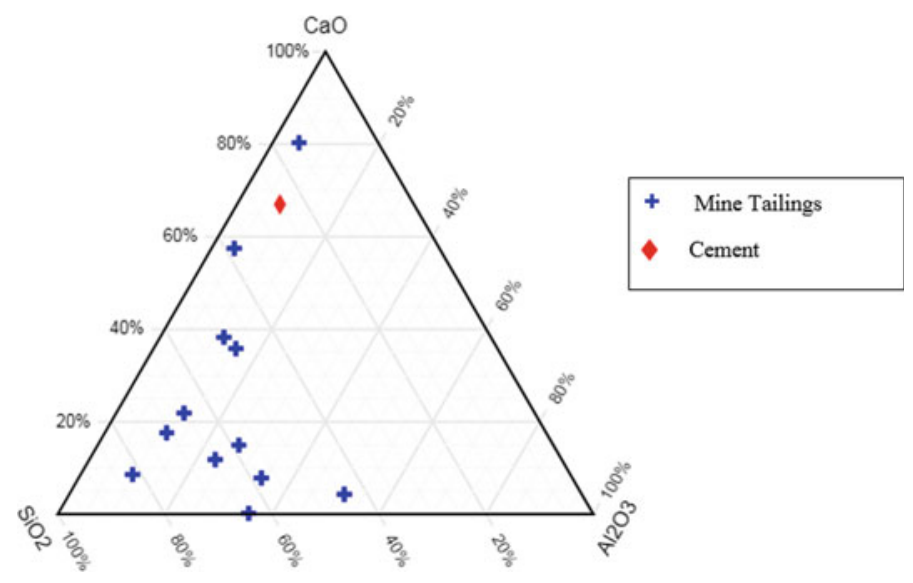

Fig. 21.1 Chemical Composition of Mine tailings

the major concerns associated with use of mine tailings. The past studies evaluated the feasibility and effect of use of mine tailings in various applications.

\subsubsection{Bricks}

Mine tailings can be used as an alternative to natural fine aggregates in brick production thus reducing the demand on sand mining in river beds. Fired clay bricks prepared using hematite mine tailings were found to be achieving a strength of 12.65 to 20.35 $\mathrm{MPa}$ and water absorption was found to be in range of $16.5-17.9 \%$ when the firing temperatures were varied from $850-1050{ }^{\circ} \mathrm{C}$ [14]. Optimum firing temperature was found to be $950-1000{ }^{\circ} \mathrm{C}$ [17]. Production of geopolymer bricks using copper mine tailing indicated that the strength increased with increase in molarity of the activator. However, the effective optimisation of water content and forming pressure plays a crucial role in pore structure and hence influences the compressive strength and water absorption of the bricks. [18]

\subsubsection{Tiles}

The minerals in mine tailings change from one phase to another with temperature. This property, makes mine tailing a suitable raw material for use in tiles and ceramics. When traditional tiles and ceramics impose increased demand on kaolinite and clay, use of mine tailings may prove to be an environment friendly and economical alternative. Kinnunen et al. [4] considered chemically bonded ceramics and geopolymerisation technology as two methods most suitable for effectively using mine tailings 
Fig. 21.2 Furniture made of mine tailing in a heritage site in Portugal [20]

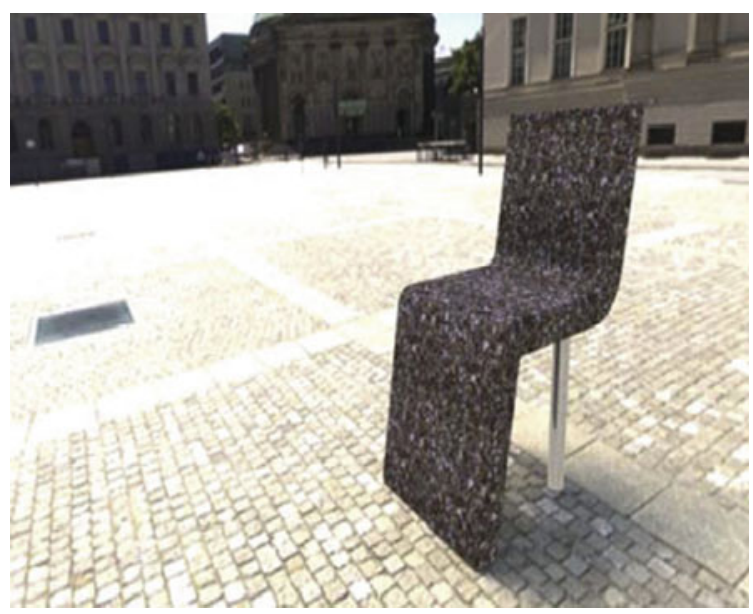

in ceramics. Hematite tailings proved to be an efficient fluxing agent in production of porcelain tiles, when used in percentages between 50 and $70 \%$. Water absorption and porosity of the tiles decreased with increase in percentage of mine tailings and a strength up 72.5 MPa was achieved [19]. Gomez et al. [20] attempted the production of terrazzo tiles for decorative purposes using tungsten mine wastes and resin. The aged mine tailings were of a visually appealing ochre colour, whereas the heated tailing was reddish in colour owing to Iron oxidation. The samples were heated at $600{ }^{\circ} \mathrm{C}$ to obtain the desired colour. This colour variation makes application of mine tailings extendable use in heritage structures where the variation in colour of repair material is a major requirement. One such application in shown in Fig. 21.2.

\subsubsection{Fine Aggregate}

With the increased demand and shortage of quality fine aggregate, the alternative sources for fine aggregates are being explored globally [21]. Mine tailing as a replacement of fine aggregate in mortar and concrete has been studied widely, mainly due to its particle size and specific gravity. Borges et al. [22] reported that though the use of iron tailing as sand has no effect on strength properties, it affected the durability due to increased porosity and water absorption. Wang et al. [13] studied the freeze thaw performance of mortar samples with graphite mine tailings as fine aggregates. For short term cycles $40 \%$ replacement and for long term cycles $20 \%$ replacement performed better than control mixes. When gold mine tailings were used as a sand replacement a maximum strength of $47 \mathrm{MPa}$ was achieved at 30\% replacement. [10] 


\subsubsection{Coarse Aggregates}

A very few studies have been carried out on use of mine tailings as coarse aggregate. Development of conductive concrete using graphite mine tailing as coarse aggregates was carried out by Liu et al. [23]. It was observed that strength reduced by about $29-42 \%$ for $15 \%$ replacement. The concrete with mine tailings performed well with respect to conductivity. The conductivity improved by about $50 \%$ for $15 \%$ replacement. This extends the applicability to de-icing/snow melting concrete for pavements in cold weather conditions and for applications where cathodic protection of reinforcement is required.

\subsubsection{Cementitious Binders}

Mine tailings may be used in cementitious binders as a raw material for clinker, as a supplementary cementitious material, as a direct cement replacement or as a precursor for alkali activated materials. For such applications, chemical and physical modification of mine tailings by thermal treatment, alkali activation and grinding may be performed to achieve desirable properties. Laura et al. [24] suggested that coal mine waste when activated, could be used as direct cement replacement. Mortar of 42.5 MPa and 32.5 MPa strength were obtained with 20 and 50\% replacement and Ince [10] reported an optimum replacement percentage of 30\%. Vargas and Lopez [25] reported that copper mine tailings when used as a supplementary cementitous material improved the mortar strength. Malagon et al. [26] used 7\% of coal mining waste as a raw material for production of cement clinker and observed a 9-14\% decrease in strength due to hindering of hydration by the $\mathrm{Cu}$ ions present in the mine waste. Calcination of tungsten mine waste with $\mathrm{Na}_{2} \mathrm{CO}_{3}$, followed by activation using sodium hydroxide solution yields high early age strength up to $45 \mathrm{MPa}$ [27].

\subsection{Discussions and Conclusions}

The use of mine tailings have also been extended to other civil engineering applications such as cemented back fill [28], soil stabilization, landfill and embankments [29]. The past studies indicate the possibility of production of high strength cement and building components using mine tailings. The use of mine tailings in these building components and construction processes not only has the potential to reduce the demand on the existing natural resources but it could also provide an effective and environment friendly way of disposal of mine tailings. However, these applications have to be considered with caution taking into account the leaching of heavy metals and the possibility of acid mine drainage. With application of alkali activation [30], hydration [31], chemical bonding [4] such risks can be minimised and the mine tailings can be used with greater confidence. 


\section{References}

1. Sustainable Built Environments | Vivian Loftness I Springer (2016)

2. G. Blight, Mine waste: a brief overview of origins, quantities, and methods of storage. Waste, 77-88 (2011)

3. D. Kossoff, W.E. Dubbin, M. Alfredsson, S.J. Edwards, M.G. Macklin, K.A. Hudson-Edwards, Mine tailings dams: Characteristics, failure, environmental impacts, and remediation. Appl. Geochemistry 51, 229-245 (2014)

4. P. Kinnunen et al., Recycling mine tailings in chemically bonded ceramics-a review. J. Clean. Prod. 174, 634-649 (2018)

5. J.S. Adiansyah, M. Rosano, S. Vink, G. Keir, A framework for a sustainable approach to mine tailings management: disposal strategies. J. Clean. Prod. 108, 1050-1062 (2015)

6. L. Yu, Z. Zhang, X. Huang, B. Jiao, D. Li, Enhancement experiment on cementitious activity of copper-mine tailings in a geopolymer system. Fibers 5(4), 1-15 (2017)

7. O. Onuaguluchi, Ö. Eren, Recycling of copper tailings as an additive in cement mortars. Constr. Build. Mater. 37, 723-727 (2012)

8. F. Pacheco-Torgal, J.P. Castro-Gomes, S. Jalali, Investigations on mix design of tungsten mine waste geopolymeric binder. Constr. Build. Mater. 22(9), 1939-1949 (2008)

9. R. Argane et al., Geochemical behavior and environmental risks related to the use of abandoned base-metal tailings as construction material in the upper-Moulouya district, Morocco. Environ. Sci. Pollut. Res. 23(1), 598-611 (2016)

10. C. Ince, Reusing gold-mine tailings in cement mortars: mechanical properties and socioeconomic developments for the Lefke-Xeros area of Cyprus. J. Clean. Prod. 238, 117871 (2019)

11. J. Esmaeili, H. Aslani, Use of copper mine tailing in concrete: strength characteristics and durability performance. J. Mater. Cycles Waste Manag. 21(3), 729-741 (2019)

12. A.M.T. Simonsen, S. Solismaa, H.K. Hansen, P.E. Jensen, Evaluation of mine tailings' potential as supplementary cementitious materials based on chemical, mineralogical and physical characteristics. Waste Manag. 102, 710-721 (2020)

13. Z.R. Wang, B. Li, H.B. Liu, Y.X. Zhang, X. Qin, Degradation characteristics of graphite tailings cement mortar subjected to freeze-thaw cycles. Constr. Build. Mater. 234, 117422 (2020)

14. Y. Chen, Y. Zhang, T. Chen, Y. Zhao, S. Bao, Preparation of eco-friendly construction bricks from hematite tailings. Constr. Build. Mater. 25(4), 2107-2111 (2011)

15. Q. Wan, F. Rao, S. Song, R. Morales-Estrella, X. Xie, X. Tong, Chemical forms of lead immobilization in alkali-activated binders based on mine tailings. Cem. Concr. Compos. 92(May), 198-204 (2018)

16. J. Kiventerä, L. Golek, J. Yliniemi, V. Ferreira, J. Deja, M. Illikainen, Utilization of sulphidic tailings from gold mine as a raw material in geopolymerization. Int. J. Miner. Process. 149, 104-110 (2016)

17. C. Yang, C. Cui, J. Qin, X. Cui, Characteristics of the fired bricks with low-silicon iron tailings. Constr. Build. Mater. 70, 36-42 (2014)

18. S. Ahmari, L. Zhang, Durability and leaching behavior of mine tailings-based geopolymer bricks. Constr. Build. Mater. 44, 743-750 (2013)

19. Y. Chen, Y. Zhang, T. Chen, T. Liu, J. Huang, Preparation and characterization of red porcelain tiles with hematite tailings. Constr. Build. Mater. 38, 1083-1088 (2013)

20. J.P. Castro-Gomes, A.P. Silva, R.P. Cano, J. Durán Suarez, A. Albuquerque, Potential for reuse of tungsten mining waste-rock in technical-artistic value added products. J. Clean. Prod. 25, 34-41 (2012)

21. S.K. Kirthika, S.K. Singh, A. Chourasia, Alternative fine aggregates in production of sustainable concrete-a review. J. Clean. Prod., 122089 (2020)

22. P.H.R. Borges, F.C.R. Ramos, T.R. Caetano, T.H. Panzerra, H. Santos, Reuse of iron ore tailings in the production of geopolymer mortars. Rev. Esc. Minas 72(4), 581-587 (2019)

23. H. Liu, K. Liu, Z. Lan, D. Zhang, Mechanical and electrical characteristics of graphite tailing concrete. Adv. Mater. Sci. Eng. 2018 (2018) 
24. L. Caneda-Martínez, M. Frías, C. Medina, M.I.S. de Rojas, N. Rebolledo, J. Sánchez, Evaluation of chloride transport in blended cement mortars containing coal mining waste. Constr. Build. Mater. 190, 200-210 (2018)

25. F. Vargas, M. Lopez, Development of a new supplementary cementitious material from the activation of copper tailings: Mechanical performance and analysis of factors. J. Clean. Prod. 182, 427-436 (2018)

26. B. Malagón, G. Fernández, J.M. De Luis, R. Rodríguez, Feasibility study on the utilization of coal mining waste for Portland clinker production. Environ. Sci. Pollut. Res. 27(1), 21-32 (2020)

27. F. Pacheco-Torgal, S. Jalali, Influence of sodium carbonate addition on the thermal reactivity of tungsten mine waste mud based binders. Constr. Build. Mater. 24(1), 56-60 (2010)

28. J. Zheng, Y. Zhu, Z. Zhao, Utilization of limestone powder and water-reducing admixture in cemented paste backfill of coarse copper mine tailings. Constr. Build. Mater. 124, 31-36 (2016)

29. I. Vegas, M. Cano, I. Arribas, M. Frías, O. Rodríguez, Physical-mechanical behavior of binary cements blended with thermally activated coal mining waste. Constr. Build. Mater. 99, 169-174 (2015)

30. F. Rao, Q. Liu, Geopolymerization and its potential application in mine tailings consolidation: a review. Miner. Process. Extr. Metall. Rev. 36(6), 399-409 (2015)

31. J. Nouairi et al., Study of $\mathrm{Zn}-\mathrm{Pb}$ ore tailings and their potential in cement technology. J. African Earth Sci. 139, 165-172 (2018)

Open Access This chapter is licensed under the terms of the Creative Commons Attribution 4.0 International License (http://creativecommons.org/licenses/by/4.0/), which permits use, sharing, adaptation, distribution and reproduction in any medium or format, as long as you give appropriate credit to the original author(s) and the source, provide a link to the Creative Commons license and indicate if changes were made.

The images or other third party material in this chapter are included in the chapter's Creative Commons license, unless indicated otherwise in a credit line to the material. If material is not included in the chapter's Creative Commons license and your intended use is not permitted by statutory regulation or exceeds the permitted use, you will need to obtain permission directly from the copyright holder.

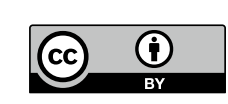

